Thorax (1976), 31, 585.

\title{
Pulmonary hypersensitivity to Ramin (Gonystylus bancanus)
}

\author{
A. D. HOW I E, G. BOY D, a nd F. MOR A N \\ Centre for Respiratory Investigation, Royal Infirmary, Glasgow G4 OSF
}

\begin{abstract}
Howie, A. D., Boyd, G., and Moran, F. (1976). Thorax, 31, 585-587. Pulmonary hypersensitivity to Ramin (Gonystylus bancanus). Transient airways obstruction associated with reduction in the transfer factor (diffusing capacity) of the lungs is reported in a patient with a clinical syndrome in keeping with extrinsic allergic alveolitis after exposure to Ramin dust (Gonystylus bancanus). The alterations in pulmonary function were consistently demonstrated on testing the patient in his working environment and were reproduced in the laboratory after inhalational challenge. The importance of the temporal relationship of changes in pulmonary function to contact with suspected allergenic material is emphasized.
\end{abstract}

Respiratory disease has been described after the inhalation of a number of different wood dusts. The pattern of response varies and is dependent on the causative agent. Symptoms similar to an immediate asthmatic reaction may develop a few minutes after contact, and this has been described after exposure to oak (Sosman et al., 1969) and to Western red cedar (Gandevia and Milne, 1970; Chan Yeung et al., 1973). A delayed reaction, with the onset of symptoms several hours after exposure, has been observed after contact with Western red cedar (Pickering, Batten, and Pepys, 1972; Chang-Yeung et al., 1973), Cedar of Lebanon (Sosman et al., 1969; Greenberg, 1972), and Iroko (Pickering et al., 1972). A combination of immediate and late reactions has been noted after exposure to Western red cedar (ChanYeung et al., 1973) and to mahogany (Sosman et al., 1969).

Evidence is accumulating to suggest that the bronchial reactions to wood dusts are mediated by immunological mechanisms rather than simply by mechanical irritation of the bronchial mucosa, as suggested by Michaels (1967). Precipitins have been detected in patients' serum to extracts of a variety of wood dusts, namely, oak, mahogany, cedar (Sosman et al., 1969), and Iroko (Pickering et al., 1972), although other workers have failed to demonstrate this reaction to extracts of Western red cedar (Chan-Yeung et al., 1973).

We describe a further example of inhalational disease caused by wood dust in a worker handling
Ramin (Gonystylus bancanus) and stress the importance of the provocation inhalation test in confirming the diagnosis.

\section{CASE REPORT}

A 34-year-old non-smoking male presented with a two-year history of episodes of breathlessness, cough, shivering, sweating, and tiredness which occurred four to six hours after periods of heavy exposure to Ramin dust. He remained symptom free during weekends and holiday periods when he was away from the factory environment. Physical examination, a chest radiograph, electrocardiogram, full blood count including eosinophil count, ESR, prick tests for immediate hypersensitivity to inhalant antigens (Bencard) including Ramin dust extract, and pulmonary function tests performed during the initial assessment were normal. The history suggested a hypersensitivity reaction within the bronchopulmonary tree similar to that found in extrinsic allergic alveolitis, and this was further supported by the presence of precipitins in the patient's serum to saline extracts of fresh Ramin dust. Precipitins were not detected in the serum of eight of his fellow workers.

Investigation was carried out with his full and informed consent. Baseline pulmonary function assessment was completed on a Sunday when he had been free from exposure to Ramin for 48 hours. The next morning he worked in the factory for a normal four-hour shift and was ex- 
posed to high concentrations of Ramin dust. After exposure serial measurements of static and dynamic lung volumes together with estimation of transfer factor (diffusing capacity) for carbon monoxide by the single breath method were made in the laboratory at two-hourly intervals for the next eight hours and again at 24 hours. This procedure was repeated on three occasions over a three-month period. In addition, an inhalation provocation test was performed in the laboratory by instructing the patient to shake dust obtained from the factory from one open tray to another in a confined space, as described by Pepys, Pickering, and Loudon (1972). The results are shown in the Figure.

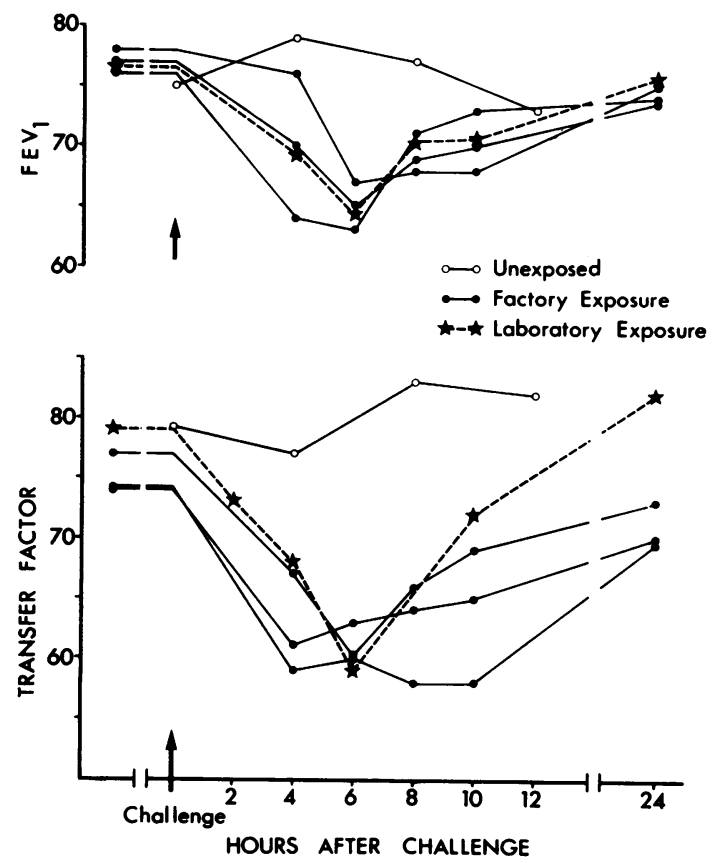

FIGURE Changes in FEV (upper trace) and transfer factor (lower trace) expressed as percentage of mean predicted normal after challenge with Ramin dust at the time indicated by the broad arrow on three occasions in the factory and in the laboratory.

\section{COMMENT}

The patient tolerated the periods of dust exposure well but on each occasion developed chest tightness and malaise several hours later, similar to the symptoms with which he presented. The three challenges in the factory and the one in the laboratory showed significant reduction in trans $\frac{}{0}$ fer factor $(P<0.0025$, paired Student's test) foun to six hours after exposure with return to base $\mathbb{D}$ line values after 24 hours. The reduction of the transfer factor was not associated with a significant rise in carboxyhaemoglobin levels following $\vec{\circ}$ the repeated single breath manoeuvre, nor with any alteration in the alveolar volume computed for each measurement. Therefore, the low value recorded after exposure reflected a true impair ${ }_{\omega}^{x}$ ment of gas transfer. The changes in the lung volumes were more variable, but a significant fall in $\mathrm{FEV}_{1}$ was found on each occasion $(\mathrm{P}<0.0025)$ The pulmonary function results are in accord with those of Sosman et al. (1969), who found similar? alterations in transfer factor and lung volumes in patients who developed delayed onset of symp toms after exposure to mahogany and cedar. Theo studies by Pepys and Jenkins (1965) showed? similar changes in lung function in patients witho acute symptoms of farmer's lung. By contrast, the studies following challenge with Western redcedar, in which patients developed either an im mediate, a late, or a combination of immediate and late asthmatic reactions, demonstrated severen airways obstruction but information regardingp changes in the transfer factor was inconclusive.

The patient's history, the reduction in transfe? factor, and the demonstration of precipitins to Ramin dust in the serum supported the diagnosis of an extrinsic allergic alveolitis. Changes in pul monary function were consistently documentec $\vec{b}$ after exposure to Ramin dust in his norma working environment, and these were reproduced experimentally in the laboratory. The fall in trans 3 . fer factor was demonstrated only after inhalation challenge. This stresses the importance of the temporal relationship of changes in pulmonary function to contact with suspected allergenic material. Ramin (Gonystylus bancanus) is a fure ther example of an organic dust which canicause the clinical syndrome of extrinsic allergios alveolitis.

\section{REFERENCES}

Chan-Yeung, M., Barton, G. M., MacLean, L., and Grzybowski, S. (1973). Occupational asthma an rhinitis due to Western red cedar (Thuja plicata) American Review of Respiratory Disease, 108, 1094.

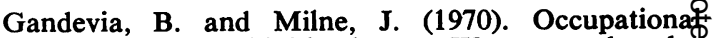
asthma and rhinitis due to Western red cedap (Thuja plicata), with special reference to bronchial reactivity. British Journal of Industrial Medicine, 27, 235. 
Greenberg, M. (1972). Respiratory symptoms following brief exposure to Cedar of Lebanon (Cedra libani) dust. Clinical Allergy, 2, 219.

Michaels, L. (1967). Lung changes in woodworkers. Canadian Medical Association Journal, 96, 1150.

Pepys, J. and Jenkins, P. A. (1965). Precipitin (F.L.H.) test in farmer's lung. Thorax, $20,21$.

Pepys, J., Pickering, C. A. C., and Loudon, H. W. G. (1972). Asthma due to inhaled chemical agentspiperazine dihydrochloride. Clinical Allergy, 2, 189.

Pickering, C. A. C., Batten, J. C., and Pepys, J. (1972). Asthma due to inhaled wood dusts-
Western red cedar and Iroko. Clinical Allergy, 2, 213.

Sosman, A. J., Schlueter, D. P., Fink, J. N., and Barboriak, J. J. (1969). Hypersensitivity to wood dust. The New England Journal of Medicine, 281, 977.

Requests for reprints to: Dr. A. D. Howie, Centre for Respiratory Investigation, Royal Infirmary, Glasgow G4 OSF. 